\title{
The Ujir Site: An Early Historic Maritime Settlement in Northwestern Aru
}

\author{
Peter Veth ${ }^{1}$, Sue $0^{\prime}$ Connor $^{2}$, Matthew Spriggs², Widya Nayati ${ }^{3}$, Ako Jatmiko ${ }^{4}$ and Husni Mohammad ${ }^{5}$ \\ 1. Research Unit, Australian Institute of Aboriginal and Torres Strait Islander Studies, Canberra, ACT, Australia \\ 2. Archaeology and Natural History, Research School of Pacific and Asian Studies, \\ The Australian National University, Canberra, ACT, Australia \\ 3. Department of Archaeology, Gajah Mada University, Yogyakarta, Indonesia \\ 4. Puslit Arkenas, Jakarta, Indonesia \\ 5. Puslit Arkenas, Branch Menado, Indonesia
}

\section{Introduction}

This chapter is an expansion of Veth et al. (2000) and includes additional information. During archaeological reconnaissance of the western coasts of the Aru Islands in 1995 a remarkable complex of major stone ruins was located near the contemporary village of Ujir (Fig. 5.1). Initial inspection of the settlement revealed a considerable number of stone structures covering what appeared to be several architectural phases. The structures are heavily overgrown by secondary rainforest and are located directly adjacent to a sungai or tidal channel, forming a deep natural harbour.

Despite the claim of local villagers that the settlement was a benteng portuguese or Portuguese fort, the majority of the structures appeared to be of non-European origin. However, two heavily concreted cannons and an anchor of European origin have been found near the settlement. Their original provenance and relationship to the built structures were unclear.

A mystery presented itself. The only other major historic stone buildings in the Aru Islands were well documented, and comprised three mid-17th century Dutch V.O.C. forts at Wangil, Wokam and Dosi (see for instance Merton 1910; Valentijn 1862[1722]), yet here was a major settlement of significantly greater areal extent than the documented Dutch forts. We

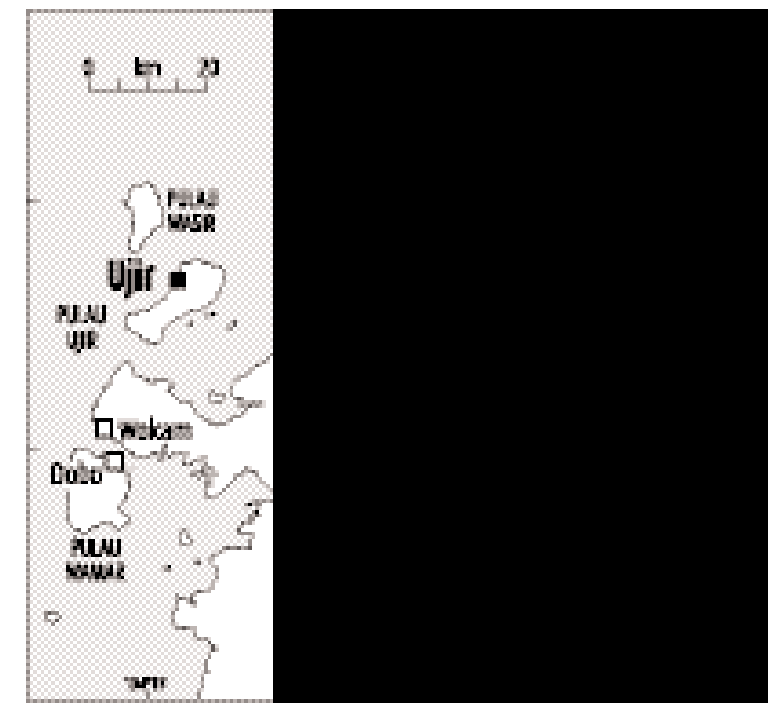

Figure 5.1 The village site of Ujir on Pulau Ujir on the northwest coast 


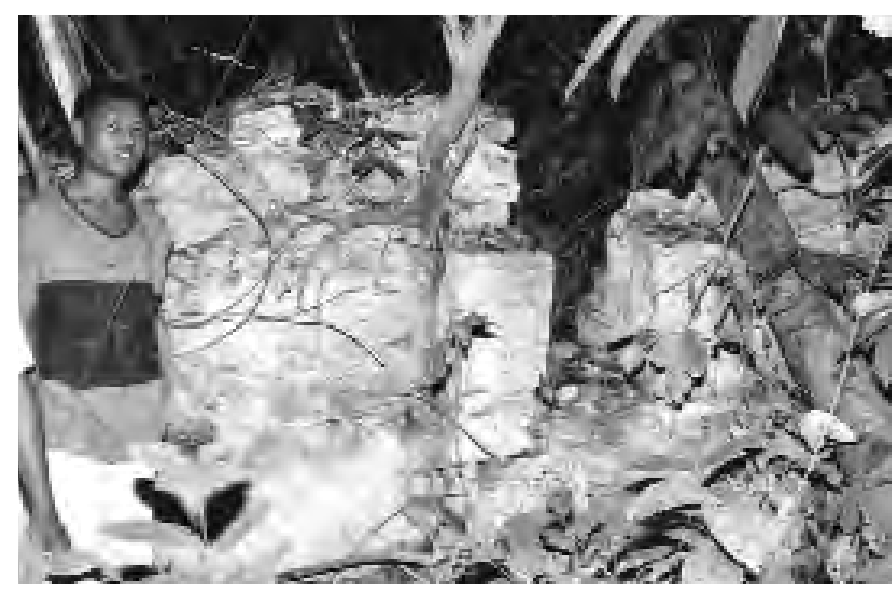

Figure 5.2

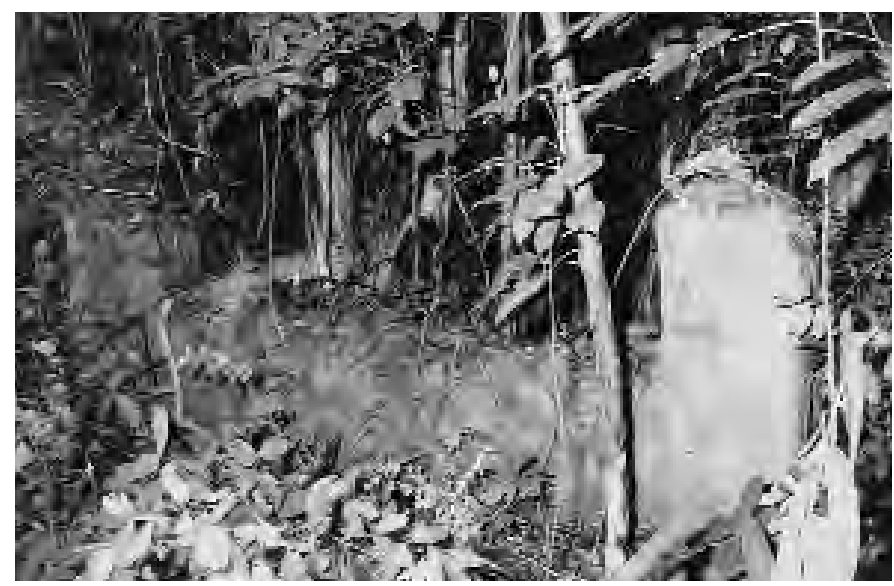

Figure 5.3

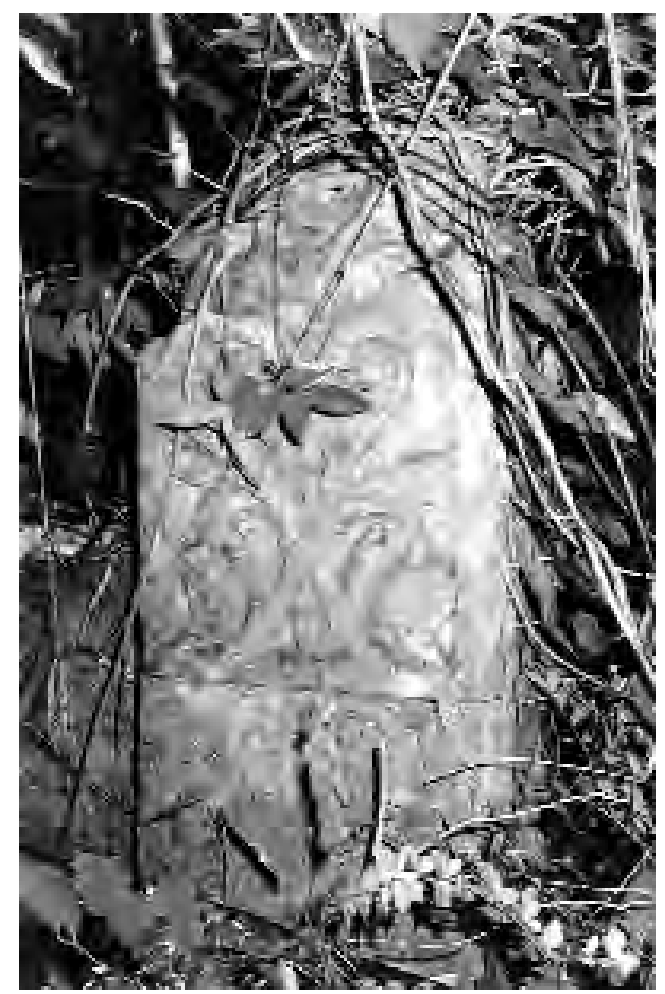

Figure 5.4

Figures 5.2 to 5.4 Ujir: coral block walls and columns showing plasterwork with non-figurative designs in relief originally thought it was previously unrecorded, but upon our return from the field we found that others too had pondered over these mystery structures and their origin.

\section{A Summary Description of the Structures}

Further visits to the site in 1996 and 1997 revealed that the Ujir settlement (labelled Site 5 in our reconnaissance surveys) covered many hectares. To plan the structures accurately would involve clearing dense vegetation and secondary forest. As many of the strangler roots are actually growing through the walls this presents a major conservation problem, as removal of the vegetation would destabilise the structures. Even a survey of the structures would be a major undertaking. Here we simply aim to provide a preliminary description of the extent of the site and the architectural affinities of Ujir.

The structures are all made from coral blocks, some with walls preserved to heights of up to three metres, which were plastered. The plaster bears non-figurative designs in relief (Figs 5.2-5.4). Some of the structures comprise long continuous walls of over $20 \mathrm{~m}$ length (where still extant), whereas others are square to rectangular in plan and approximately four metres across. Several have small windows of semi-circular form, with plaster relief designs embellishing both the inside and outside (Figs 5.5, 5.6). A number of these rooms, or chambers, are flanked by square columns topped by chamfered edges, and what appear to be truncated spires. In an earlier paper (Spriggs et al. 1998) we stated that the chambers lacked entrance doorways and must have been entered via the roof. Our reconnaissance in 1997 revealed that some chambers have narrow doorway entrances. 
Near the settlement, a number of large stone-walled grave enclosures with headstones were recorded. These are also built from cut coral blocks and are plastered (Fig. 5.7). They are typical of the so-called historic long graves associated with Islamic men of high status (James Fox pers. comm.) The relationship of the graves to the settlement is not certain, however.

The most prominent and best preserved of the structures is perched on the edge of the sungai at the inland (east) edge of the site. It is a large rectangular stone building with buttressing and arched windows, sitting on a stone revetment wall. The arched windows of the original structure have subsequently been infilled with coral boulders (Fig. 5.8). Iron lintels are exposed in the arched windows and plate impressions were noted on the apex of the window, probably indicating where china plates formed part of the ornamentation around the windows at some time. The local villagers refer to this building as a mesjid or mosque, and suggested that it had been built later than the other structures in the area. It appears that its use as a mosque is a re-use of a structure that may have originally been a fortified position. We were told in Ujir that the mosque was

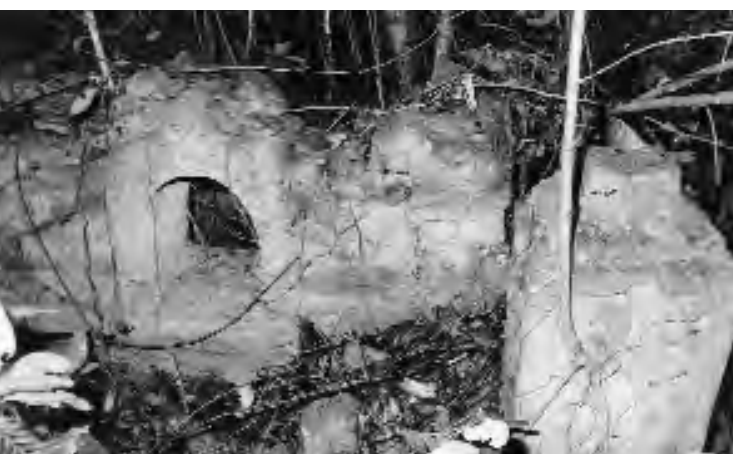

Figure 5.5

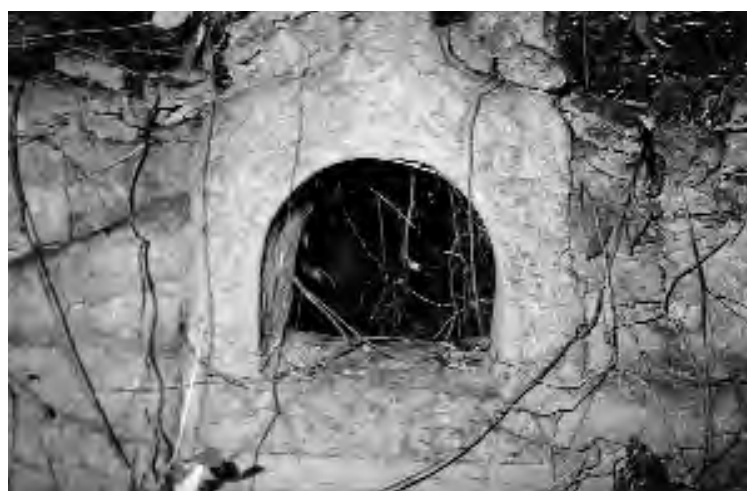

Figure 5.6

Figures 5.5 and 5.6 Ujir: coral block structures with semi-circular windows displaying plaster relief designs embellishing both the inside and the outside destroyed by Allied bombing in World War II.

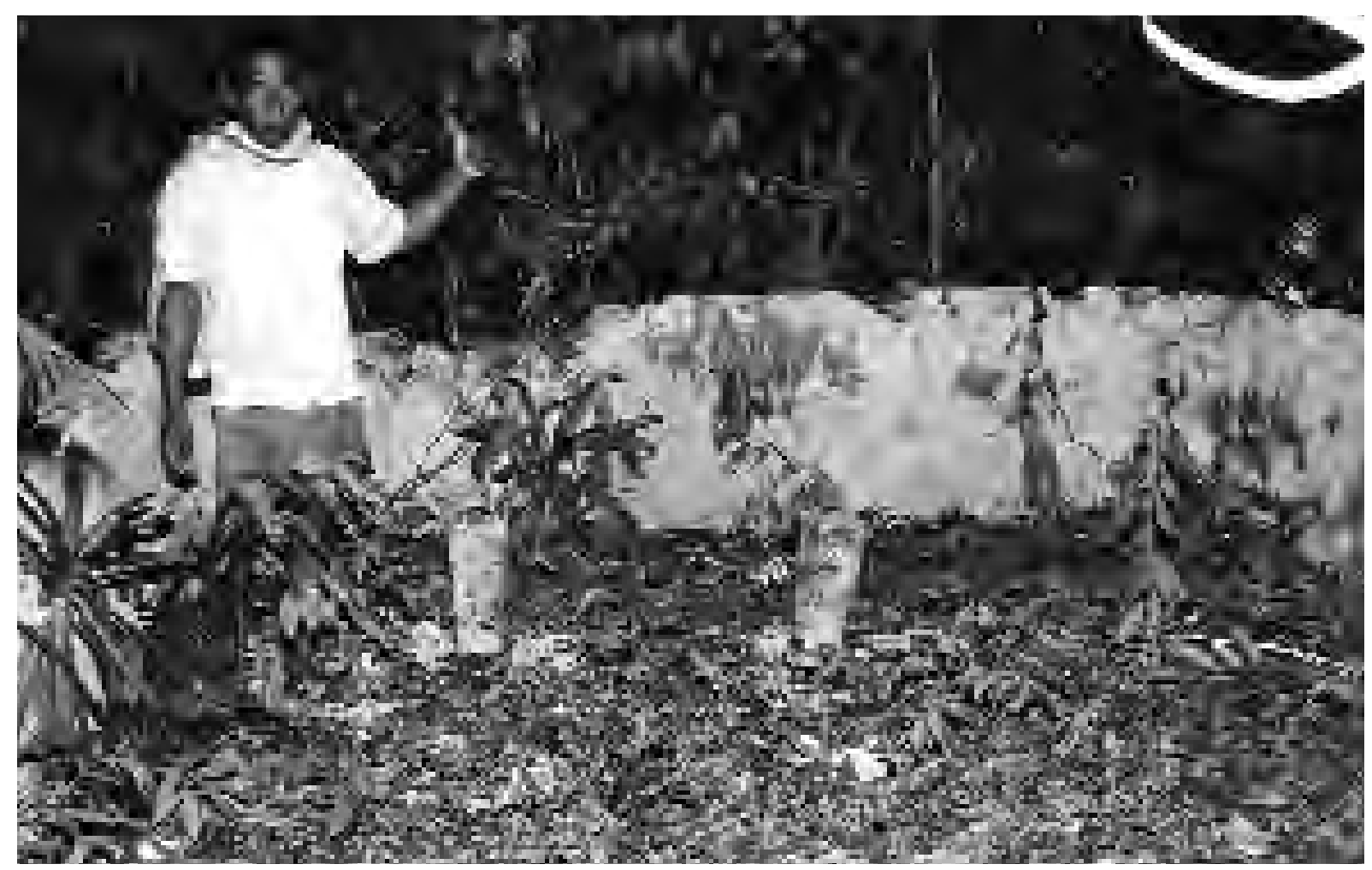

Figure 5.7 Ujir: Islamic long grave with headstones and walls made from plastered coral blocks 


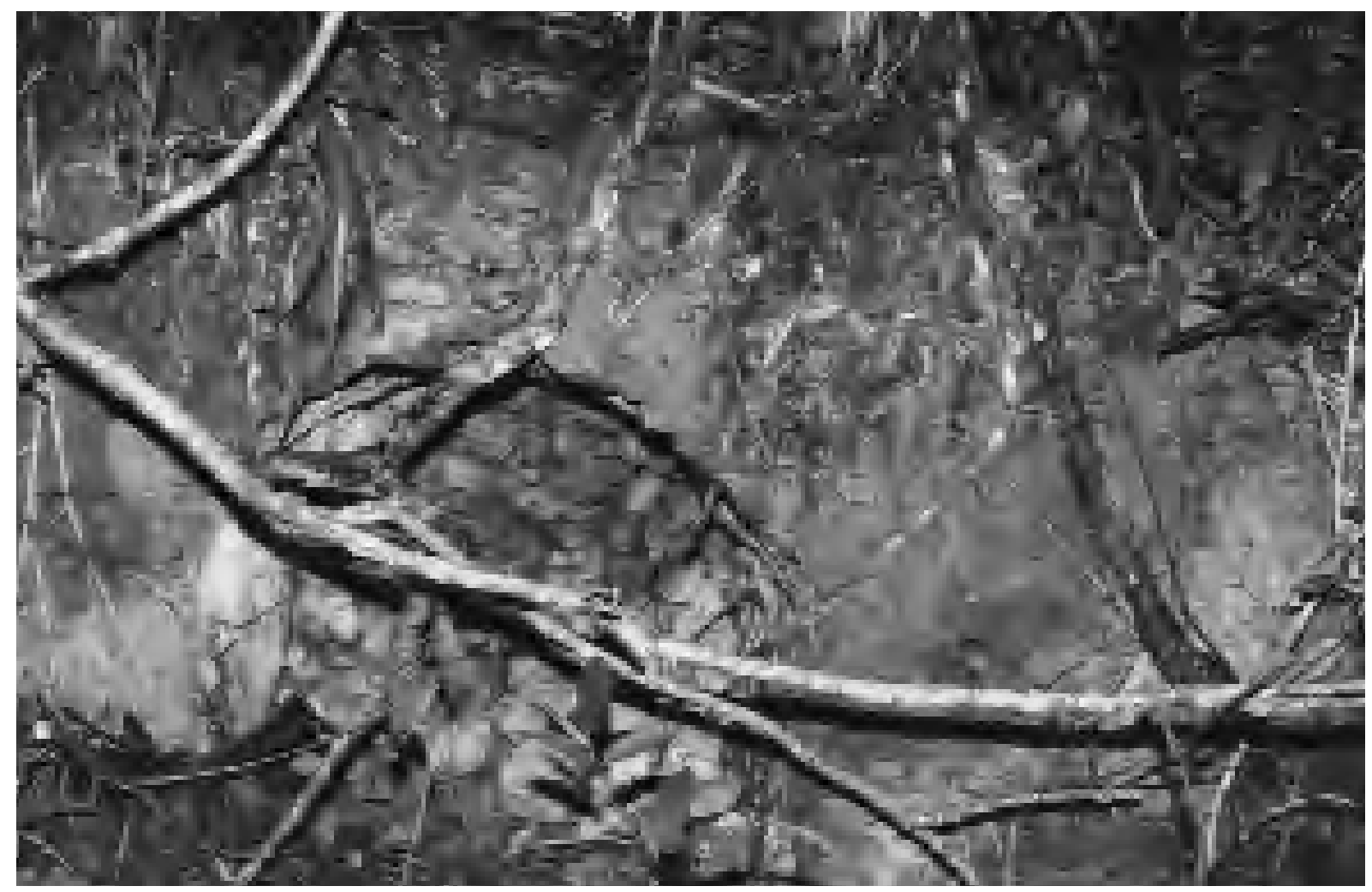

Figure 5.8 Ujir: details of infilled arched window at previous fortification

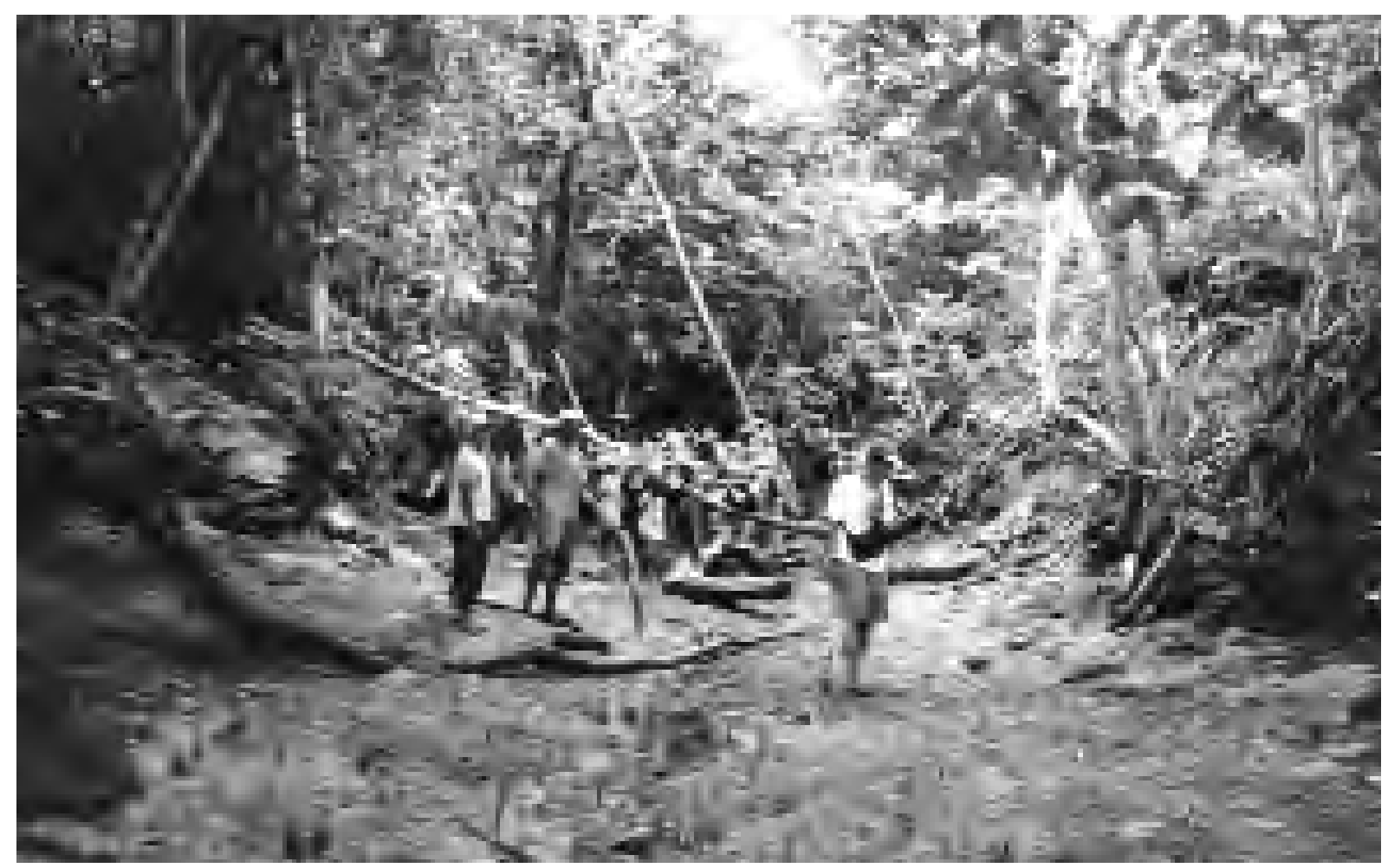

Figure 5.9 Natural tidal creek that may have been artificially extended. The banks of the channel are covered in shell midden and chinese and Dutch ceramics 
To the west of this structure is a natural tidal creek, separating it from the other remains of the settlement (Fig. 5.9). The creek appears to have been artificially extended landward to create a deep water channel or seawater moat at high tide. This is referred to by the local villagers as Fuabil. The upper banks of this channel are covered with shell midden of approximately 10$15 \mathrm{~cm}$ in thickness, comprising mainly mangrove species such as Terebralia sp. and Anadara sp. Earthenware pottery sherds appear to be eroding from at least the upper portion of the shell lens. Neither Chinese nor European porcelain were recorded in the shell midden, and it is possible that the midden predates the appearance of such ceramics. In the intertidal zone at the mouth of the creek and extending around to the mosque along the shore of the sungai is a substantial amount of Chinese, Dutch and what might be Middle Eastern trade ceramics, earthenware pottery, as well as square-based glass bottles. In addition, occasional metal fragments and a gun flint were found adjacent to the mosque.

The cannons were recovered by villagers from near the mosque. One heavily corroded cannon still rests in the sand at the edge of the sungai, while the other has been relocated to

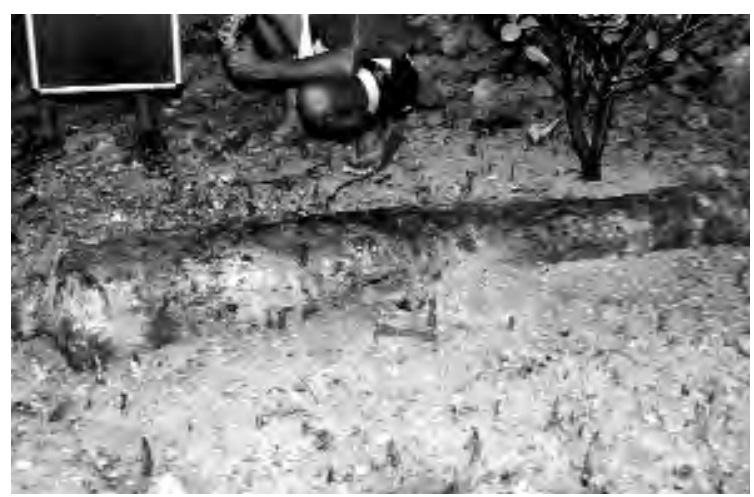

Figure 5.10 Ujir: weathered cannon found lying in the intertidal zone

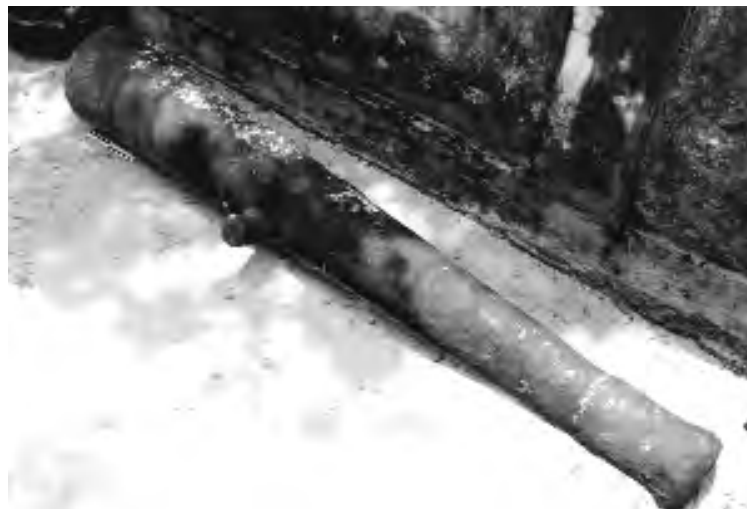

Figure 5.11 Ujir: view of the cannon which has been relocated to the contemporary mosque from the previous fortification outside the modern mosque in the village of Ujir

(Figs 5.10, 5.11). Insignia are not visible on the heavily concreted cannons but they are consistent with 16th or 17th century ordnance of European origin. A large stone mortar also lies in the intertidal zone next to the mosque.

A large section of the steep earthen embankment along the edge of the sungai, west of the inlet, is reinforced by large cut coral blocks. The villagers refer to this as yan vallender, which they gloss as the Dutch steps, from belanda, referring to Europeans such as the Dutch as 'Hollanders'.

\section{Historic Sources Relating to Ujir}

It is possible that the fortified structure represents a previously unknown Portuguese or Dutch fort. But the problem with this interpretation is that there is little evidence for any Portuguese activity in the Aru archipelago, and the Dutch period of influence seems well documented. The Portuguese were never successful in establishing either fort or factory in the Banda Group (Villiers 1981:740) and so can probably be ruled out as candidates.

Before and during the period of Portuguese presence in the region, the people of Banda controlled most of the trade with Aru and nearby island groups (Villiers 1981, 1990), purchasing sago, birds of paradise, and parrots in return for cloth. The sourcing of the red-slipped pottery found in the Wangil midden to Banda (see Chapter 6, this volume) would suggest that this trade link was of pre-colonial antiquity, and that pottery as well as cloth went from Banda to Aru. Some gold is also said to have come from Aru (Markham 1911:85), but its ultimate origin must have been 
from West New Guinea, perhaps through another trade route via the Gorom and Seram-Laut islands at the eastern end of Seram down to Aru (Goodman 1998; Villiers 1981:742).

The first Portuguese voyage to the Moluccan region occurred in 1512, but there is no evidence that they visited Aru directly. Claims to the contrary (repeated by Spyer 1992:58) result from a mistranslation of the description of that voyage (Courtesao 1944:lxxxiii, footnote 1). Galvao's account of the voyage (cited by Wood 1922:69) mentions that the products of 'Arus' consisted of '.. delicate birds which are of great estimation because of their feathers'. As Courtesao points out (ibid.) this passage is not describing Abreu's voyage, but the trading voyages of the Javanese. Spyer $(2000: 82,87)$ reports an oral history tradition of the 'Portugis' as the 'first comers' to Aru. However, she recognizes that in Indonesia the term 'Portugis' is used as a generic label to describe all 'first comers' prior to the Dutch, regardless of their nationality (Spyer 2002:303).

The Suma Oriental of Tomo Pires, written in 1512-15 from information obtained in Melaka, has this to say of Aru:

The nore parrots [lories] come from the island of Papua. Those which are prized more than any others come from the islands called Aru (Ilhas Daru), birds which they bring over dead, called birds of paradise (passaros de Deus), and they say they come from heaven, and that they do not know how they are bred; and the Turks and Persians use them for making panaches [plumes for hats] — they are very suitable for this purpose. The Bengalees buy them. They are good merchandise, and only a few come (Cortesao 1944:209).

Villiers reports (1981:741) that the Portuguese often referred to the birds as passaros de Banda, believing that they died in the Banda Islands. Portuguese knowledge of Aru was largely indirect as implied by the attribution of birds of paradise to Banda, but its presence on maps in roughly its correct position by 1530-36 shows that they had probably at least sailed around it by that time. It is labelled 'Arrum' on the so-called Dauphin Chart of that period (Collingridge 1906:32-3; Wood 1922:115), as 'Arru' on the Desceliers map of 1550 (Collingridge 1906:68-9), and as 'Aruu' on Mercator's 1569 map (Wood 1922:91).

Earlier in the 14th century the Majapahit kingdom of Java extended its influence to the Moluccas to obtain regular spices. The sphere of influence and dominance of trade claimed by the Indonesian kingdom of Majapahit in 1365 is given in the Negarakertagama poem, written in the old Javanese by the poet Prapanca. Both Ambwan (Ambon) and Moloko (the Northern Moluccas) are mentioned. Contact with Java stimulated the development of a number of sultanates, such as Ternate in the northern Moluccas (Reid 1995:315; Swadling 1996:23). While the influence exerted by this Kingdom in southeast Maluku is unknown, outside influence in the form of Islam had spread to the region by the third quarter of the 15th century, through the trade contacts between the Bandanese, Javanese, and Malay traders (Ellen 1990; Lape 2000a; Villiers 1981:731).

The Islamic-influenced structures of Ujir would appear to be testimony to this trade relationship - the settlement probably being based around the production of sago and the supply of birds of paradise. Obviously, systematic recording and excavation is now required to test this proposition.

In 1623 the Governor of Ambon dispatched two ships under Jan Carstensz to sign a treaty of friendship with the orang kaya or merchant-aristocrats of prominent villages on the west coast of Aru (Spyer 1992:58, 60, 63). The most important were Ujir, Wamar, Wokam and Maikoor. From then on, these villages played a prominent role acting as mediators in local disputes in the archipelago, and as representatives of the Dutch rulers during periods of indirect rule when there was no official colonial presence in Aru. By the early 19th century, the archipelago had been divided into four districts under the rule of these villages. Spyer (1992:63) notes that: 
The main thrust of the 1623 treaty was an effort to revive the ancient trade between Banda and Aru which had come to a halt during the extermination wars in Banda in the first quarter of the sixteenth [sic — should be seventeenth] century ... The renewal of this trade under a VOC monopoly would have enabled the Dutch to cut down on the high costs of transporting foodstuffs from Java to Banda through the import of sago and other garden produce from the Aru Islands.

She also reports on a subsequent agreement of 1645 for these same villages to trade exclusively with Dutch-controlled Banda (Spyer 1992:62; see also Loth 1998:67 on Banda trade). Perhaps the fortified structure was Dutch-inspired rather than Dutch-built.

Kolff's 1826 visit to Ujir, called by him Wadia, provides the first direct reference to the ruins we have been able to find. The village may have been bigger then than it is now, as he reports structures also on the left bank of the sungai:

After entering the creek we passed a temple and a number of tombs, and soon arrived at the village, which lies about a cable's length and a half from the mouth. The houses, which stand separated from each other, are erected on both sides of the river, but by far the greater number are to be found on the right hand side, the dwelling of the Orang Kaya forming a conspicuous object among them (Kolff 1840:206).

Kolff reported on the trade in birds of paradise from the village, noted sago and yams as productions of the island, and that the inhabitants obtained rice from Macassans, and from Kei and Goram traders who picked it up from Banda. He continues:

During our stay here I examined the neighbourhood of the village, and met with some former strongholds, the remains of which proved that they must have been extensive. We also found the traces of a long street, enclosed with walls, running east and west through the village, together with the ruins of many stone houses. The natives could give us no clear information concerning them (Kolff 1840:216).

Kolff also offers some support for our interpretation of the structure later used as a mosque as being Dutch-inspired rather than of Dutch origin. He reported on a dispute between Ujir and a village called 'Fannabel' on the northeast side of Wokam Island. The Orang Tua of Fannabel was said to have 'possessed a stone building, defended by cannon' (Kolff 1840:213), which may have been of a similar type.

Further clues to the antiquity and importance of Ujir come from the treatise on the Aru Islands by van Hoevell (1890) and from the German zoologist Merton (1910). During a trip to the Aru Islands in 1888 Baron van Hoevell (1890:8) noted that the stone mosque of Ujir could be seen from the estuary (sungai). Of interest is his observation that Ujir had the most substantial fortified walling of any of the 'indigenous' communities and that there appeared to be extensive walls / structures from an earlier time period.

Similar observations were made by Merton (1910:166) on his visit to the settlement in 1908, when he noted (translated into English by A. and A. Veth):

When we entered the Ujir sungai, we had before us a wonderful landscape, more beautiful than we had ever seen here. A wide sungai, which was framed by mangroves and coco-palms, and in the foreground some overhanging casuarinas, was actually nothing new for us and yet the landscape had something strange. On one bank on a jutting out rock stood a rectangular building constructed from stone; its palm leaf roof was finished step-like. That was the mosque of Ujir ... When we went ashore, everything also made an unusual impression. At a small jetty we got out; from here a well kept road led to the village, past Moslem graves, which had been made partly of stone and partly of wood. The village itself was surrounded by stone walls; often the plots of land belonging to a house were also bordered by walls from the neighbouring 
one ... Ujir consists of many houses, and is one of the largest places of the Aru Islands ... In the village itself in various places were the remainders of stone foundations. On the bank there was another second jetty with stone railings. All that seems to indicate a higher culture, which must have gained a firm footing here for quite some time. Probably the East India Company had obtained a firm footing here for some time. Unfortunately I could find out nothing at all from the less than friendly population.

The link with the VOC of course is just Merton's speculation and we have seen no documents which support this. It is interesting that his report is similar to Kolff's in suggesting that the villagers either did not know or were unwilling to indicate an origin for the structures. Our experience was somewhat similar.

In terms of the age and origins of the extensive ruins at Ujir with Islamic-inspired architecture it is worth considering the likely role of the Aru Islands in the wider trading systems associated with commodities such as birds of paradise and spices, which historical sources date back to at least 2000 years ago (Swadling 1996). The central role of the Bandas as a trading entrepot for these valuable commodities is well documented (Meilink-Roelofsz 1962; Villiers 1981). Lape (2000b, 2002) similarly documents a site in Banda (BN1), the construction of which was dated to the 16th century but which does not appear to be European built, or even inspired, and which may have been part of general defensive orientation as conflicts became more a part of trading, as there was more orientation of traders to Islam.

\section{Conclusions}

On the basis of architectural construction, the nature of the decorative plasterwork and the presence of 'long graves', the ruins of Ujir are clearly non-European, whilst the large rectangular building is possibly an early Dutch, or at least Dutch-inspired, fort which was later modified by the Ujir villagers to serve as a mosque, the structure noted by Merton as operating in 1908 and almost certainly that referred to as a 'temple' by Kolff during his 1826 visit (1840:206).

To what extent the clearly non-European settlement overlaps in time with the supposed fort is uncertain. The historic sources for trade in other parts of the Moluccas, however, suggest that the original settlement could have been established by the late 15th century. Whoever made the structures, it is clear that a settlement of this permanence and extent implies an involvement in regional, if not global, trading systems. The degree of Aru's involvement in these early trading systems has probably been historically neglected, due in part to the dominance of the north Moluccan and Bandanese trade-polities of the 15th and 16th centuries.

The discoveries at Ujir hint that a more complex picture of wider trading relationships within the Moluccas, before the presence of Europeans, waits to be unfolded. 


\section{References}

Collingridge, G. 1906. The First Discovery of Australia and New Guinea. Sydney: William Brooks.

Courtesao, A. (trans. and ed.). 1944. The Suma Oriental of Tomo Pires. London: Hakluyt Society. Second Series LXXXIX, volume 1.

Ellen, R.F. 1990. Trade, environment, and the reproduction of local systems in the Moluccas. In E. Moran (ed.), The Ecosystems Approach in Anthropology, pp. 191-228. Ann Arbor: University of Michigan Press.

Goodman, T. 1998. The sosolot exchange network of eastern Indonesia during the seventeenth and eighteenth centuries. In J. Miedema, C. Odé, and R.A.C. Dam (eds), Perspectives on the Bird's Head of Irian Jaya, Indonesia: Proceedings of the Conference, Leiden, 13-17 October 1997, pp. 421-54. Amsterdam: Rodopi.

von Hoevell, G.W.W.C., Baron. 1890. De Aroe-eilanden, geographisch, ethnographisch en commercieel. Tijdschrift van het Koninglijk Nederlandsch Aardrijkskundig Genootschap, Leiden 33:57-102.

Kolff, D.H. 1840. Voyages of the Dutch Brig of War 'Dourga' through the Southern and Little Known Parts of the Moluccan Archipelago... during the Years 1825 and 1826. London: James Madden.

Lape, P. V. 2000a. Political dynamics and religious change in the late pre-colonial Banda Islands, eastern Indonesia. World Archaeology 32(1):138-55.

Lape, P.V. 2000b. Contact and Conflict in the Banda Islands, Eastern Indonesia, 11th to 17th Centuries. Unpublished PhD thesis, Brown University, Rhode Island.

Lape, P.V. 2002. Historic maps and archaeology as a means of understanding late pre-colonial settlement in the Banda Islands, Indonesia. Asian Perspectives 41:43-70.

Loth, V. 1998. Fragrant gold and food provision: resource management and agriculture in seventeenth century Banda. In S. Pannell and F. Von Benda-Beckmann (eds), Old World Places, New World Problems: Exploring Issues of Resource Management in Eastern Indonesia, pp. 66-93. Canberra: Australian National University.

Markham, Sir C. (trans. and ed.). 1911. Narrative of the Voyage to Malucos or Spice Islands by the Fleet under the Orders of the Commander Garcia Jofre de Loaysa, in Early Spanish Voyages to the Straits of Magellan. London: Hakluyt Society, Second Series XXVII.

Meilink-Roelofsz, M.A.P. 1962. Asian Trade and European Influence Between 1500 and 1630. The Hague: Martinus Nijhoff.

Merton, H. 1910. Forschungsreise in den Sudostlichen Molukken (Aru-und Kei Inslen). Frankfurt, A.M.: Senckenbergischen Naturforschenden Gesellschaft. English translation by A. and A. Veth (1998), James Cook University, Townsville.

Reid, A. 1995. Continuity and change in the Austronesian transition to Islam and Christianity. In P. Bellwood, J.J. Fox, and D. Tryon (eds), The Austronesians: Historical and Comparative Perspectives, pp. 314-31. Canberra: Department of Anthropology.

Spriggs, M., P. Veth, and S. O'Connor. 1998. In the footsteps of Wallace: the first two seasons of archaeological research in the Aru Islands, Maluku. Cakalele: Maluku Studies Research Journal 9(2):63-80.

Spyer, P. 1992. The Memory of Trade: Circulation, Autochthony, and the Past in the Aru Islands (Eastern Indonesia). Unpublished PhD thesis, Department of Anthropology, The University of Chicago, Chicago.

Spyer, P. 2000. The Memory of Trade: Modernity's Entanglements on an Eastern Indonesian Island. Durham \& London: Duke University Press.

Swadling, P. 1996. Plumes From Paradise: Trade Cycles in Outer Southeast Asia and Their Impact on New Guinea and Nearby Islands Until 1920. Port Moresby: Papua New Guniea National Museum in association with Robert Brown and Associates (Queensland).

Valentijn, F. 1862[1722]. Oud en Nieuw Ost-Indien: met Aanteekeningen, Volledige Inhoudsregisters, Chronologische Lijsten, enz. Volume III. 's-Gravenhage: H.C. Susan.

Veth, P., S. O'Connor, M. Spriggs, W. Nayati, A. Jatmiko, and H. Mohammad. 2000. The mystery of the Ujir site: insights into early historic settlement in the Aru Islands, Maluku. The Bulletin of the Australian Institute for Maritime Archaeology 24:125-32.

Villiers, J. 1981. Trade and society in the Banda Islands in the sixteenth century. Modern Asian Studies 15 (4):723-50.

Villiers, J. 1990. The cash-crop economy and state formation in the Spice Islands in the fifteenth and sixteenth centuries. In J. Kathirithamby-Wells and J. Villiers (eds), The Southeast Asian Port and Polity: Rise and Demise, pp. 83-105. Singapore: Singapore University Press.

Wood, G.A. 1922. The Discovery of Australia. London: Macmillan. 